\title{
PENGGUNAAN ASAP CAIR CANGKANG PALA (Myristica fragrans) SEBAGAI BAHAN PENGAWET PADA PENGOLAHAN IKAN TONGKOL (Euthinnus affinis) ASAP
}

\author{
Neil Steward Lala ${ }^{1}$, Jenki Pongoh ${ }^{2}$ dan Nurmeilita. Taher ${ }^{2}$ \\ ${ }^{1)}$ Mahasiswa pada Program Studi Teknologi Hasil Perikanan FPIK Unsrat Manado \\ ${ }^{2)}$ Staf pengajar pada Program Studi Teknologi Hasil Perikanan FPIK Unsrat Manado \\ Email: lalaneilsteward@yahoo.com.
}

\begin{abstract}
The purpose of this research is to determine the quality of the smoked mackerel tuna (Euthynnus affinis) processed with liquid smoke from nutmeg shell at various concentration $(6,8$ or $10 \%$ ) by drying for 6 hours or 8 hours. The tested parameters tested were moisture content, $\mathrm{pH}$, organoleptic and texture. The lowest water content (36.25) and $\mathrm{pH}$ value (5.5) was obtained from a smoked fish that was dried for 8 hours using $10 \%$ liquid smoke. The organoleptic results of taste and smell indicated that the panelists preferred smoked fish which was made with $6 \%$ concentration of liquid smoke and dried for 6 hours.
\end{abstract}

\begin{abstract}
Keyword: Mackerel tuna, liquid smoke, nutmeg shell.
Ikan tonggkol (Euthynnus affinis) adalah salah satu jenis ikan yang banyak terdapat di perairan Indonesia terlebih khusus di daerah Sulawesi Utara. Pengolahan ikan menggunakan asap cair memiliki beberapa kelebihan antara lain, mudah diterapkan dan praktis penggunaannya polusi ke lingkungan dapat diperkecil dan yang paling penting senyawa karsinogen yang terbentuk dapat dieliminasi. Asap cair cangkang Pala dapat dijadikan solusi. Tujuan dari penelitian ini yaitu mengetahui penggunaan asap cair cangkang Pala dengan konsentrasi 6, 8, 10\% terhadap mutu ikan tongkol (Euthynnus affinis) asap. Manfaat yang di peroleh dari penelitian ini ialah mengetahui penggunaan asap cair dari cangkang pala yang direndam pada ikan tongkol dengan konsentrasi berbeda-beda, dengan perlakuan perendaman pada konsentrasi $6,8,10 \%$ dengan pengeringan selama 6 jam dan pengeringan selama 8 jam. Dengan parameter uji Kadar air, pH, Organoleptik dan Tekstur. Hasil yang diperoleh dari ikan tongkol asap cair cangkang pala konsentrasi $6,8,10 \%$. Kadar air dengan pengeringan selama 6 jam memiliki kadar air tertinggi kosentrasi $6 \%, 44,75 \% .8 \%, 38,75 \%$. 10\%, 36,25\%. Dan pengeringan selama 8 jam memiliki kadar air terendah. Hasil pH dari ikan tongkol asap cair cangkang Pala dengan konsentrasi 6\%, $8 \%, 10 \%$. Dengan pengeringan selama 6 jam memiliki nilai tertinggi yaitu konsentrasi $6 \%, 5,76.8 \%, 5,65.10 \%$, 5,61. dan pengeringan selama 8 jam memiliki nilai terendah. Organoleptik kenampakan setelah dari uji direngking diperoleh konsentrasi 10\% yang dikeringkan 6 jam memiliki nilai terting gi yaitu 66,5 Untuk organoleptik bau setelah di uji rengking konsentrasi 6\% dikeringkan selama 6 jam memiliki nilai tertinggi yaitu 59,5. Organoleptik rasa setelah dari uji rengking dengan konsentrasi 6\% dengan lama pengeringan 6 jam memiliki nilai tertinggi 75,5. Dan untuk tekstur dimana konsentrasi $10 \%$ dengan pengeringan 8 jam memiliki nilai terendah 0,28 dari konsentrasi lainnya.
\end{abstract}

Kata Kunci: Ikan tongkol, asap cair, cangkang pala.

\section{PENDAHULUAN}

Ikan sebagai salah satu sumber bahan makanan yang dibutuhkan oleh manusia karena banyak mengandung protein. Di pihak lain banyaknya kandungan air yang terdapat pada ikan membuat ikan cepat mengalami proses penurunan mutu atau pembusukan. Oleh karena itu pentingnya upaya menghambat proses tersebut dengan cara pengawetan dan pengolahan. Salah satu cara pengolahan ialah dengan pengasapan. Dalam pengasapan ikan, komponen-komponen kimia yang terdapat dalam asap memegang peranan penting karena membentuk warna yang khas, dapat mengawetkan dan menghambat kerusakan pada produk pangan.

Indonesia salah satu negara yang kaya akan tanaman berkhasiat sebagai obat-obatan dan rempah-rempah yang tersebar di berbagai daerah, seperti di provinsi Sulawesi Utara yaitu tanaman Pala. Banyaknya potensi dalam bidang pertanian menyebabkan banyaknya limbah dan mengandung bahan organik yang dapat dimanfaatkan. Pemanfaatan cangkang Pala masih kurang sehingga membuat limbah dari 
hasil pertanian ini semakin bertambah (Tempomona, 2015)

Ikan tongkol (Euthynnus affinis) adalah salah satu jenis ikan yang banyak terdapat di perairan Indonesia terlebih khusus di daerah Sulawesi Utara. Dengan harganya yang relatif murah dan ketersediaan yang melimpah, ikan ini banyak dikonsumsi oleh masyarakat baik diolah menjadi ikan asap.

\section{METODOLOGI PENELITIAN}

Metode yang digunakan dalam penelitian ini adalah bersifat eksploratif, dimana menurut Mantjoro dan Manus (1987) metode ini bersifat eksploratif adalah penelitian yang dilakukan untuk mengungkapkan dan mengetahui suatu fakta tertentu secara terperinci dan sistematik.

\section{Tempat dan Waktu Penelitian}

Pelaksanaan penelitian ini dilaksanakan di Laboratorium Penanganan dan Pengolahan Hasil Perikanan Fakultas Perikanan dan Ilmu Kelautan, Universitas Sam Ratulangi Manado. Penelitian dilaksanakan selama 3 bulan JuniAgustus 2016.

\section{Alat dan Bahan}

Peralatan yang digunakan adalah seperangkat alat pembuatan asap cair seperti tungku pembakaran, wadah kondensasi dari styrofoam, botol aqua, toples dan kompor, oven, pisau, keranjang ikan. Peralatan untuk analisa kadar air: oven, desikator, timbangan analitik, cawan porselen, spatula, mortar dan pastle, $\mathrm{pH}$ meter, baker glass.

Bahan yang digunakan dalam penelitian ini adalah cangkang Pala yang dibeli pada penjual, ikan tongkol segar, Pala dalam bentuk cangkang dan produk asap cairnya, es balok, akuades, larutan buffer.

\section{Perlakuan}

Perlakuan yang digunakan dalam penelitian ini adalah Perlakuan (A) Konsentrasi Asap cair.

1. $\mathrm{A} 1=6 \%$

2. $\mathrm{A} 2=8 \%$

3. $\mathrm{A} 3=10 \%$

(B) $=6$ jam dan 8 jam Pengeringan

\section{Tatalaksana Penelitian}

Adapun tahapan penelitian adalah sabagai berikut:
1. Cangkang Pala dibeli kemudian di timbang $\pm 10 \mathrm{~kg}$;

2. Cangkang Pala dimasukan kedalam tungku pembakaran secara bertahap;

3. Asap dialirkan melalui pipa besi diameter $7,5 \mathrm{~cm}$;

4. Asap kembali dialirkan pada pipa paralon diameter $8 \mathrm{~cm}$;

5. Es sebanyak 7 balok sebagai media pendingin;

6. Asap cair di tampung pada wadah toples atau botol.

Diagram alir prosedur Penelitian

Ikan tongkol segar $3 \mathrm{~kg}$

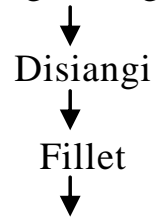

Direndam Pada konsentrasi Asap cair 6\%, 8\%, 10\% Selama 30 Menit

Keringkan dalam oven selama 6 dan 8 jam, suhu 60-850C

Ikan Asap Cair cangkang pala

Analisa Kadar Air, pH, Uji tekstur dan Organoleptik

\section{HASIL DAN PEMBAHASAN}

Analisa Kadar Air

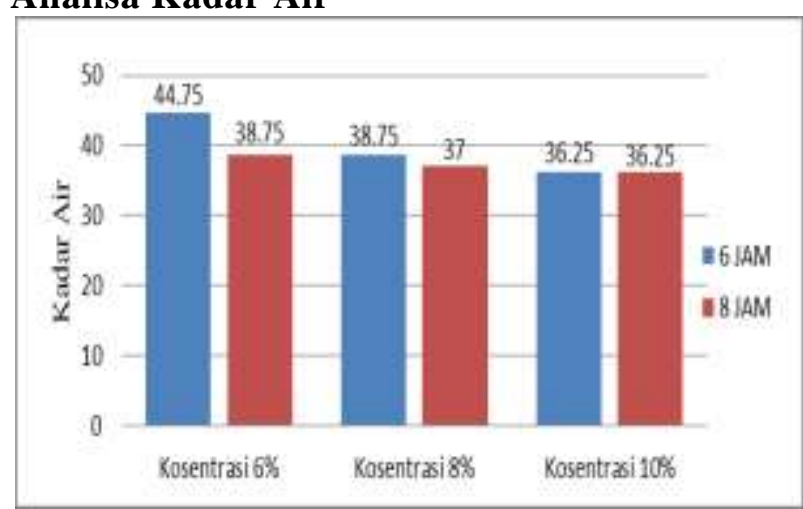

Gambar 1. Histogram Nilai kadar air ikan Tongkol (Euthynnus affinis) Asap. Keterangan:

Filet ikan tongkol asap dikeringkan selama 6 jam

Fillet ikan tongkol asap dikeringkan selama 8 jam

Kadar air dari fillet ikan tongkol asap yang telah direndam dalam larutan asap cair dengan konsentrasi 6, 8 dan 10\%, dengan lama pengeringan pada suhu selama 6 dan 8 jam memiliki kisaran $44,75 \%$ dan pengeringan 
selama 8 jam kadar airnya 36,25\% untuk melihat lebih jelas nilai rata-rata kadar air dari fillet ikan tokol asap dapat di tampilkan pada Gambar 1.

Gambar 1. Menunjukan bahwa bila dilihat dalam histogram di atas nilai rata-rata kadar air ikan asap cair cangkang pala dengan konsentrasi $6 \%$ dengan lama pengeringan 6 jam memperoleh hasil tertinggi yakni $44,75 \%$. Sedangkan untuk nilai kadar air terendah adalah $36,25 \%$ diperoleh dari fillet ikan tongkol dengan konsentrasi asap cair cangkang buah pala $10 \%$ yang dikeringkan selama 6 jam. Oleh sebab itu melihat dari hasil kedua konsentrasi yang berbeda dengan lama pengeringan yang sama dan mendapatkan nilai kadar air terendah $36,25 \%$ dengan konsentrasi $10 \%$. Maka dapat di simpulkan kadar air ikan tongkol asap cair cangkang pala dapat di simpan dengan daya awat waktu yang lama.

Untuk kadar air ikan tongkol asap cair cangkang pala dengan konsentrasi $6 \%$ dengan lama pengeringan 8 jam memperoleh hasil tertinggi yakni $38,75 \%$ Sedangkan untuk kadar air terendah di peroleh oleh ikan asap cair cangkang pala dengan konsentrasi $10 \%$ dengan lama pengeringan 8 jam yakni $36,25 \%$ Bila dilihat keduanya faktor lama pengeringan dapat mempengaruhi kandungan kadar air yang terdapat pada ikan asap cair cangkang pala pada masing-masing konsentrasi. Menurut Hardianto $d k k$ (2015). tingginya kadar air disebabkan oleh lama waktu perendaman yang relatif pendek dan konsentrasi yang kurang beragam menyebabkan proses penguapan air saat pengeringan menjadi tidak stabil sehingga kadar air masih tinggi. Pengawetan dengan menggunakan asap cair untuk produk dan bahan pangan dipanggang atau dikeringkan pada temparatur $82^{\circ} \mathrm{C}$ di peroleh kadar air sekitar 54,0-63,5\% (Winsniewski and Menrer, 1979 dalam Pongoh, 2001).

Tingginya kadar air pada produk dapat mempengaruhi mutu terutama berhubungan erat dengan daya awet bahan selama penyimpanan, karena mempengaruhi sifat-sifat fisik (misalnya pengerasan, pengeringan) dan sifat fisika-kimia, perubahan-perubahan kimia misalnya pencoklatan pada bahan pangan, tumbuhnya kapang pada permukaan ikan. (Buckle, $d k k$. 1987) Oleh karena itu maka kandungan air harus dikurangi sedapat mungkin agar supaya bahan terhindar dari mikroba dan mutu daya tahan bahan pangannya semakin panjang. (Rampengan, $d k k$. 1985).

\section{pH (Tingkat Keasaman)}

Derajat keasaman dari fillet tongkol asap yang direndam dalam asap cair dengan konsentrasi 6, 8 dan $10 \%$ lalu dikeringkan pada suhu $60^{\circ} \mathrm{C}$ selama 6 jam memiliki kisaran 5,76 hingga 5,61 dan fillet ikan tongkol asap cair yang dikeringkan dengan 8 jam memiliki kisaran 5,71 hingga 5,54. Untuk melihat lebih jelasnya mengenai nilai rata-rata derajat keasaman dari fillet ikan tongkol asap dapat ditampilkan pada Gambar 2. Nilai Histogram $\mathrm{pH}$.

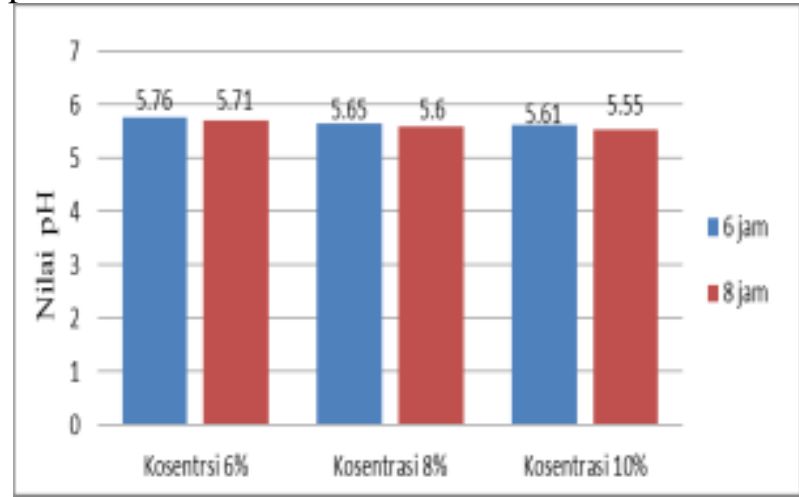

Gambar 2. Nilai Histogram pH Ikan tongkol (Euthynnus affinis) Asap.

Keterangan:

Filet ikan tongkol asap dikeringkan selama 6 jam.

Fillet ikan tongkol asap dikeringkan selama 8 jam

Secara umum bila dilihat dari histogram Gambar 2 di atas bahwa nilai rata-rata derajat keasaman ikan tongkol asap cair cangkang pala dengan konsentrasi $6 \%$ dengan lama pengeringan 6 jam memperoleh hasil tertinggi yakni 5,76 Sedangkan untuk nilai derajat keasaman terendah adalah 5,61 diperoleh dari fillet ikan tongkol dengan konsentrasi asap cair cangkang buah pala $10 \%$ yang dikeringkan selama 6 jam. Untuk derajat keasaman ikan tongkol asap cair cangkang pala dengan konsentrasi $6 \%$ dengan lama pengeringan 8 jam memperoleh hasil tertinggi 5,71. Sedangkan untuk derajat keasaman terendah diperoleh oleh fillet ikan tongkol asap cair cangkang pala dengan konsentrasi $10 \%$ dengan lama pengeringan 8 jam yakni 5,55.

Darmadji dkk. (1996) dalam Himawati (2010), semakin tinggi konsentrasi asap cair yang ditambahkan pada produk maka semakin rendah nilai $\mathrm{pH}-n y a$. Rendahnya $\mathrm{pH}$ disebabkan karena daging ikan belum terdenaturasi sehingga mempermudah penyerapan senyawa- 
senyawa dari asap dalam jumlah yang cukup banyak, sehingga dapat mempengaruhi penampakan dan bau dari produk yang dihasilkan. Pada umumnya nilai $\mathrm{pH}$ bahan pangan produk asap berkisar antara 3,0-8,0 karena kebanyakan mikroorganisme tumbuh pada pH sekitar 5,0-8,0 maka hanya jeni-jenis tertentu saja yang ditemukan pada bahan pangan yang mempunyai $\mathrm{pH}$ rendah. (Buckle. Dkk. 1987.)

Tinggi rendahnya nilai $\mathrm{pH}$ dipengaruhi oleh lamanya pengasapan, dimana waktu pengasapan yang berlangsung lebih lama, maka unsur asap yang terserap dan melekat pada produk lebih banyak, dan senyawa asam yang terserap juga mengikat sehingga $\mathrm{pH}$ menjadi turun (Berhimpon, (1974) dalam Pelokang, (2010)).

\section{Uji Organoleptik}

\section{Kenampakan}

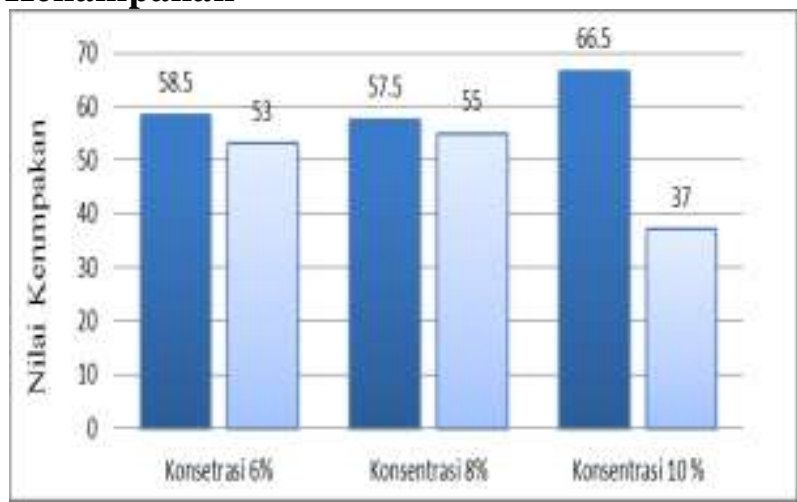

Gambar 3. Histogram nilai organoleptik kenampakan dari fillet ikan Tongkol (Euthynnus affinis) Asap.

Keterangan:

$\square \quad$ Filet ikan tongkol asap dikeringkan selama 6 jam.

Fillet ikan tongkol asap dikeringkan selama 8 jam

Dari data hasil nilai kenampakan fillet ikan tongkol asap cair cangkang pala dengan kombinasi perlakuan pemberian konsentrasi dan lama pengeringan dimana setelah data hasil pengujian fridman diperoleh kisaran pada konsentrasi $6 \%$ dengan lama pengeringan 6 jam adalah 47,5 dan 8 jam memiliki nilai 52, konsentrasi $8 \%$ dengan lama pengeringan 6 jam 56,5 dan 8 jam adalah 55 dan konsentrasi $10 \%$ dengan lama pengeringan 6 jam adalah 66,5 dan pengeringan 8 jam mendapatkan nilai 37 . Untuk melihat perubahan nilai organoleptik kenampakan fillet ikan tongkol asap dapat dilihat pada Gambar 3.

Pada Gambar 3, menunjukkan bahwa perlakuan dengan konsentrasi 6,8 dan $10 \%$ nilai organoleptik kenampakan filet ikan tongkol asap cair dari hasil pengujian friedman di peroleh bahwa hasil kombinasi perlakuan konsentrasi $10 \%$ dengan lama lama pengeringan 6 jam memiliki nilai organoleptik kenampakan tertinggi di bandingkan dengan hasil kombinasi perlakuan lainya. Dan untuk data nilai kesukaan panelis terhadap organoleptik kenampakan fillet tongkol asap hasil uji ini menunjukan adanya perbedaan yang nyata $(\mathrm{p} \leq 0,05)$ untuk setiap perlakuan terhadap tingkat kesukaan penampakan masing-masing produk. Karena adanya perbadaan yang nyata dari tiap perlakuan, maka dilakukan uji lanjut dengan Multiple Comparasion Test. Dari hasil uji ini, dapat diketahui tidak ada perbedaan antara perlakuan yang satu dengan yang lain.

Menurut Adawyah (2007) warna coklat dan warna mengkilat yang terjadi pada proses pengasapan disebabkan oleh reaksi antara fenol dengan oksigen dari udara, yang kemugkinan terjadi setelah unsur asap tersebut mengendap pada waktu pengasapan. Warna mengkilat pada ikan asap disebabkan oleh karena lapisan damar tiruan yang dihasilkan oleh reaksi antara fenol dengan formaldehida selama pengasapan.

\section{Bau}

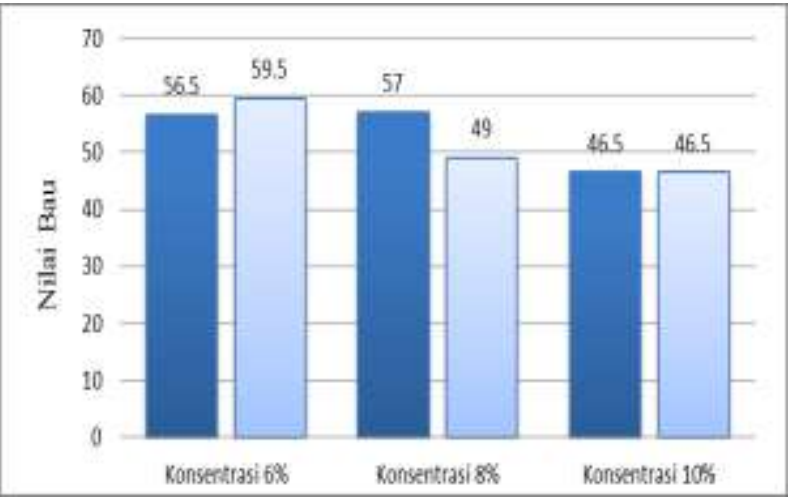

Gambar 4. Histogram nilai organoleptik bau dari fillet ikan tongkol (Euthynnus affinis) asap.

Keterangan:

Filet ikan tongkol asap dikeringkan selama 6 jam.

Fillet ikan tongkol asap dikeringkan selama 8 jam

Keadaan organoleptik bau dari fillet ikan tongkol asap yang telah direndam dalam asap cair dengan konsentrasi 6,8 dan $10 \%$ memiliki data hasil dari penggujian Friedman memiliki kisaran dimana konsentrasi 6\% dengan lama pengeringan 6 jam adalah 56,5 dan lama pengeringan 8 jam adalah 59,5 konsentrasi $8 \%$ dengan lama pengeringan 6 jam adalah 57 dan lama pengeringan 8 jam adalah 49, 
sedangkan konsentrasi $10 \%$ dengan lama pengeringan 6 jam adalah 46,5 dan lama pengeringan 8 jam adalah 46,5.

Melihat Gambar 4 di atas menunjukan bahwa perlakuan dengan konsentrasi 6,8 dan $10 \%$ nilai organoleptik bau filet ikan tongkol asap dari hasil pengujian Friedman di peroleh hasil dari perlakuan konsentrasi $6 \%$ dengan lama pengeringan 8 jam memiliki nilai organoleptik bau tertinggi adalah 59,5 dibandingakan dengan hasil kombinasi perlakuan lainya. Menurut Kapoh (1995) dalam Pagoray (2004), zat-zat yang mendominasi pembentukan aroma atau bau adalah komponenkomponen asap yang melekat pada produk. Fenol senyawa utama pembentuk aroma asap yang khas. (Wibowo,2012) adapun aroma yang dimaksud adalah aroma ke asap-asapan pada produk, dan kriteria mutu bau untuk ikan asap adalah bau asap yang lembut sampai cukup tajam, tidak tengik, tanpa bau asing, tanpa bau asam, dan tanpa bau apek.

Makanan yang masih baik memberikan bau yang khas dari bahan pangan tersebut dan tentunya akan lebih merangsang untuk dimakan. Bila baunya sudah lain atau menyimpang maka makanan tersebut dianggap sudah mulai membusuk (Harikedua, 1995 dalam Tinungki 2007).

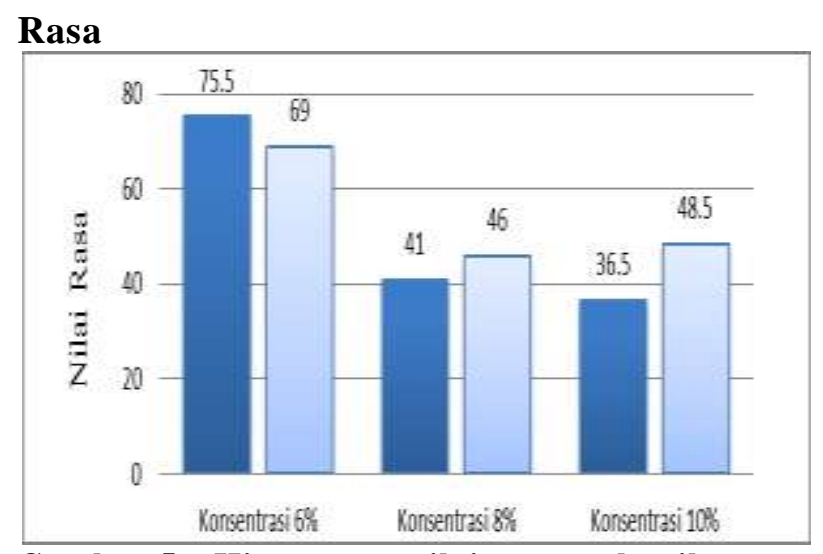

Gambar 5. Histogram nilai organoleptik rasa dari fillet ikan tongkol (Euthynnus

Keterangan: affinis) asap.

Filet ikan tongkol asap dikeringkan selama 6 jam. Fillet ikan tongkol asap dikeringkan selama 8 jam

Organoleptik rasa dari fillet ikan tongkol asap yang telah direndam dalam asap cair cangkang pala dengan konsentrasi 6, 8 dan $10 \%$. Didapatkan data hasil dari pengujian Friedman pada perlakuan konsentrasi 6\% dengan lama pengeringan 6 jam adalah 75,5, pengeringan 8 jam 69 . Konsentrasi $8 \%$ dengan lama pengeringan 6 jam adalah 41, pengeringan 8 jam adalah 46 sedangkan pada konsentrasi $10 \%$ dengan lama pengeringan 6 jam adalah 3,65 dan pengeringan 8 jam adalah 48,5. Melihat perubahan nilai organoleptik rasa filet ikan tongkol asap dapat dilihat pada Gambar 5.

Berdasarkan data hasil dari pengujian friedman yang di tunjukan pada Gambar 5. Perubahan nilai fillet dengan perlakuan menunjukan bahwa konsentrasi $6 \%$ dengan lama pengeringan 6 jam dan 8 jam memiliki nilai tertinggi yaitu merupakan respon dari rasa yang disukai. Berdasarkan dari uji friedman didapatkan perbedaan yang nyata $(p \leq 0,05)$ untuk tiap perlakuan terhadap tingkat kesukaan rasa masing-masing produk. Untuk itu dilanjutkan uji lanjut dengan Multiple Comparison Test terhadap produk, dari uji Multiple Comparison Test, dapat diketahui bahwa tidak ada perbedaan antar perlakuan yang satu dengan yang lain.

Sofos dan Busta (1980) dalam Tatengkeng (2007), menyatakan menurunya rasa asap pada produk selama penyimpanan disebabkan karena senyawa-senyawa asap seperti fenol yang mengendap pada daging ikan mengalami penguapan. Wibowo (1996) dalam Tatengkeng, (2007) menyatakan kriteria mutu organoleptik yang baik untuk rasa ikan asap adalah enak, rasa asap lembut sampai tajam tanpa rasa getir atau pahit dan tidak berasa tengik. Sofus dan Busta (1970) dalam Tinungki (2007), menyatakan Komponen-komponen fenol dari asap memiliki peranan penting dalam meresapkan citarasa.

\section{Uji Tekstur (Penetrometer)}

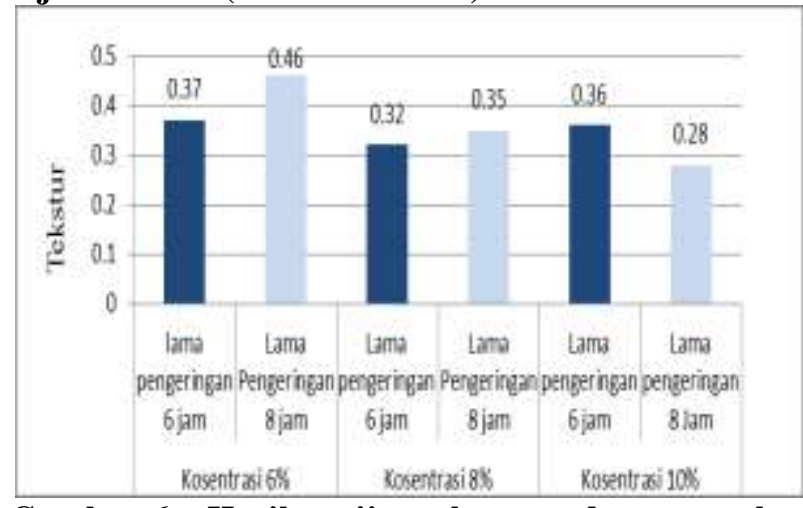

Gambar 6. Hasil uji tekstur dengan alat penetrometer.

Mutu fisik atau tingkat kekerasan fillet ikan tongkol asap cair diperoleh dari hasil 
pengukuran menggunakan penetrometer. Uji kekerasan dengan mengunakan penetrometer filet ikan tongkol asap cair cangkang pala konsentrasi 6,8 dan $10 \%$ dengan diulang sebanyak dua kali diambil pada satu titik tengah diperoleh nilai $(\mathrm{mm} / \mathrm{gr} /$ detik). Untuk melihat nilai hasil dari uji tekstur penetrometer dapat dilihat pada Gambar 6 .

Dilihat dari Gambar 6 di atas dimana konsentrasi $10 \%$ dengan lama pengeringan 8 jam nilai teksturnya yang paling rendah yaitu 0,28 dibandingan dengan konsentrasi $6 \%$ dan $8 \%$. Dengan lama pengeringan 6 dan 8 jam. Menurut Mamentu $d k k$. (2013), prinsipnya semakin kecil nilai yang didapatkan maka tingkat kekerasan semakin besar.

\section{KESIMPULAN DAN SARAN}

\section{Kesimpulan}

Kadar air ikan tongkol asap cair cangkang pala dapat diterima karena hasil yang didapatkan masih di bawah standar SNI 2725.1: 2009 yaitu $60 \%$ produk ikan asap, sedangkan kadar air ikan tongkol asap cair cangkang pala terendah dengan konsentrasi $6 \%$ selama 6 jam yaitu $44,75 \%$. Dan kosentrasi terendah $10 \%$ selama 6 jam yaitu 36,25\%. Untuk nilai $\mathrm{pH}$ ikan tongkol asap cair cangkang pala adalah 5,76\% sampai 5,55. relatif sama dengan standar SNI Ikan asap pada umumnya yaitu 5-6.

Untuk Mutu Organoleptik bau dan rasa ikan tongkol asap cair cangkang pala yang direndam pada kosentrasi $6 \%$ yang dikeringkan selama 6 dan 8 jam. mendapatkan respon yang banyak dari setiap panelis. Sedangkan konsentrasi $8 \%$ dan $10 \%$ dengan pengeringan 6 dan 8 jam mendapatkan respon yang kurang dari panelis.

\section{Saran}

Berdasarkan hasil penelitian yang di lakukan, maka disarankan:

1. Perlu dilakukan pengujian lain seperti uji mikrobiologi untuk melihat mutu produk fiilet tongkol asap cair yang direndam dalam asap cair cangkang pala.

2. Perlu dilakukan penelitian lanjutan dengan perlakuan penyimpanan untuk melihat masa simpan produk Asap cair cangkang pala ikan tongkol (Euthynnus affinis) Asap.

\section{DAFTAR PUSTAKA}

Adawyah. R. 2007. Pengolahan dan Pengawetan Ikan. Bumi Aksara Jakarta

Buckle, K.A., R.A Edwards, G.H. Fleet.and M. Woton, 1987 Ilmu Pangan. Terjemahan Hari Purnomo. Penerbit Universitas Indonesia. Press Jakarta.

Hardianto L, Yunianta 2015 Pengaruh Asap Cair terhadap Sifat Kimia Dan Organoleptik Ikan Tongkol (Euthynnus affinis). Jurnal Pangan dan Agroindustri. Vol 3 No 4.

Himawati, E. 2010. Pengaruh penambahan Asap Cair Tempurung Kelapa destilasi Dan Redistilasi terhadap Sifat Kimia, Mikrobiologi, dan Sensor Ikan Pindang Layang (Decapterus spp) Selama Penyimpanan. Skripsi, Pdf di akses pada tanggal 1 Juli 2016 Skripsi Fakultas Pertanian Universitas Sebelas Maret Surakarta.

Pagorai, M. 2005 Pengaruh Kosentrasi Dan cara pemberian Asap Cair Terhadap Mutu Organoleptik Fillet Cakalang (Katsuwonus pelamis L.) Asap. FPIK Skripsi Universitas SamRatulangi Manado.

Pelokang, 2010 Pengaruh Kosentrasi dan Cara Pemberian Asap Cair Terhadap Mutu Fillet Julung - Julung (Hemirhampus marginatus) Asap Skripsi FPIK Universitas SamRatulangi Manado.

Pongoh, J. 2001. Pengunaan Campuran Asap Cair Kalium Sorbat Secara Infiltrasi dan Diasapi Dengan Suhu Dan Lama Pengasapan yang Berbeda dan disimpan pada Suhu Dingin. Fakultas Perikanan. Universitas Brawijaya. Malang.

Rampengan V, Pontoh J, Sembel, D.T. 1985. Dasar-dasar Pengawasan Mutu Pangan. Badan Kerja Sama Perguruan Tinggi Negeri Indonesia Bagian Timur.

Tatengkeng., 2007 Pengaruh Lama Pengasapan dan Lama Penyimpanan Terhadap Mutu Ikan Layang (Decapterus sp) Asap "Pinekuhe". Skripsi FPIK Universitas Samratulangi Manado.

Tempomona Y, Rorong A, Wuntu D. Fotoreduksi Besi Fe3+ Menggunakan Ekstrak Limbah Daun Kulit, dan cangkang Biji Pala (Myristica fragrans). Jurnal Kimia MIPA,Unsrat Manado. Vol 4 (1) No 46-50.

Tinungki R, 2007. Studi Tentang fenol dan Tingkat Kesukaan Terhadap Fillet Cakalang (Katsuwonus pelamis L) Asap yang direndam dalam Asap Cair. FPIK Skripsi. Universitas SamRatulangi Manado.

Wibowo S. Widianto T, Utomo, B. 2012. Asap Cair. Cara Membuat dan

Aplikasinya Pada Pengolahan Ikan Asap. Penebar Swadaya. 